\title{
Comparative study of I ndrani Vough manufactured in the laboratory and collected from sweet meat shops of Dinajpur district
}

\author{
M Rasul $^{1}$, MN Hassan ${ }^{1 *}$, MAS Khan ${ }^{1}$, MM Sharmin ${ }^{2}$, MA I slam ${ }^{3}$ \\ ${ }^{1}$ Department of Dairy Science, Bangladesh Agricultural University, Mymensingh 2202; ${ }^{2}$ Department of Dairy \\ and Poultry Science, Hajee Mohammad Danesh Science and Technology University, Dinajpur 5200; \\ ${ }^{3}$ Department of Animal Nutrition, Bangladesh Agricultural University, Mymensingh 2202, Bangladesh
}

\begin{abstract}
This experiment was conducted to evaluate the quality of Indrani vough prepared in the laboratory and collected from Dinajpur district. Four types of Indrani vough samples were used in this experiment. Laboratory made Indrani vough was assigned as A sample. B, C and D samples were collected from Shananda sweet meat, Pabna sweet meat and Jalozogh sweet meat shop respectively. All the samples were tested for organoleptic, chemical and microbiological parameters. Among organoleptic parameters such as body and texture, color and appearance, and taste score of four types of samples differed insignificantly, but quality of samples differed significantly for flavour score $(p<0.01)$. Chemical and microbiological analyses indicated that significant differences among four types of samples were found for protein, fat, carbohydrate, ash, acidity and Total Viable Count $(p<0.01)$, except dry matter and moisture contents. From the present study it was concluded that Sananda sweet meat shop's Indrani vough was superior to others. But laboratory made Indrani vough was the best in relation to microbiological status.
\end{abstract}

Key words: Indrani vough, quality, sweet meat shop

Bangladesh Animal Husbandry Association. All rights reserved.

Bang. J. Anim. Sci. 2011. 42 (1): 71-75

\section{Introduction}

It is an almost ideal food, which supplies body building proteins, bone-forming minerals and health-giving vitamins and furnishes energy-giving lactose and milk fat and also supplies certain essential fatty acids. Its nutritive value was known for hundreds of year before it came under the concern of the science of chemistry. From nutritional point of view milk is not only the most important food for new born child but also for adolescents, adults, invalids, convalescents and patients. Milk is also converted to various milk products. Out of total production, $40 \%$ of milk is used for the manufacture of indigenous milk products and about $4 \%$ milk is converted into chhana (Mathur et al. 1991).

The sweetmeats that available in the markets of Bangladesh are mostly chhana-based milk products. The Chhan-based sweetmeats are Rasogolla, Indrani vough, Rasomalai, Chamcham, Malaikari, Kalojam, Sandesh, Kachhagolla, Rassokadam, Peda, Rajvog, Monda, Pantoa, Misti Dahi etc. Out of different types of sweetmeats Indrani vough is one of the most popular in the country especially in Dinajpur district. Actually when, where and how Indrani vough was first prepared in this country, it is not yet known.
Indrani vough is a channa based sweetmeat and it is being produced traditionally throughout the local markets of Dinajpur district. Indrani vough is widely consumed probably due to their high food value, typical flavour and high digestibility. It is highly palatable sweetmeat and very good for health because of its fairly high protein, fat, minerals, specially calcium and phosphorus contents. It mainly consists of disc shape ball and hot malai. The disc shape balls are made from freshly prepared cow milk chhana. The sugar syrap is used for heating the balls. Hot malai is prepared by boiling raw milk until light brown colour had reached.

The first pre-requisite for producing excellent quality Indrani vough is the availability of high quality chhana. Cow milk is exclusively used for chhana preparation. In the markets of Bangladesh, especially in the district of Dinajpur, Indrani vough is widely available, but the quality of this novel sweet meat varies due to differences in manufacturing procedure in different places. Like Rossomalai, Indrani vough is a very well known, delicious sweetmeat of Bangladesh. But no research work has yet been done in our country on the quality, manufacturing process or preservation technique of Indrani vough. Considering the above stated facts, the present 
experiment was undertaken to study the comparison of the organoleptic, chemical and microbiological characteristics of Indrani vough made in different sweetmeat shops of Dinajpur district of Bangladesh with Laboratory made product.

\section{Materials and Methods}

This experiment was conducted at the Dairy Science Laboratory, Bangladesh Agricultural University, during the period of 30 January 2010 to 4 March 2010. Chemical analysis was done at the Dairy Science Laboratory, Animal Science Laboratory and Central Laboratory of Bangladesh Agricultural University, Mymensingh.

\section{Preparation of Indrani vough in the Laboratory}

To prepare Indrani vough in the Laboratory, cow milk was collected from Bangladesh Agricultural University Dairy Farm. Before making chhana and malai, the milk samples were analyzed in the Laboratory to know their Fat and solids-not-fat content. For making Indrani vough 3 litre whole milk, $200 \mathrm{~g}$ sugar, $20 \mathrm{~g}$ flour and $240 \mathrm{ml}$ sour whey were used. At first 1.7 litre cow milk was heated to boil for five minutes into two separate iron pans. After heating, the samples were cooled to $80^{\circ} \mathrm{C}$ and sour whey was added until chhana separates. The contents were allowed to cool down at room temperature (About $25^{\circ} \mathrm{C}$ ), after 30 minutes the coagulam was transferred to a muslin cloth and the cloth was hung for about one hour for complete drainage of whey. $360 \mathrm{~g}$ of chhana obtained from 1.7 litre of fresh cow milk was broken and kneaded with flour $(5.5 \%$ by the weight of channa) in order to obtain the desired body and texture. Rassogolla (Disc shape) were made without the sings of cracks. Concentrated sugar syrup (sugar: water $=1.5$ : 1 ) was made and heated to boiling. Just after boiling the scum was labeled out to obtaining clear syrup. Then Rassogolla (Disc shape) of chhana were cooked in the boiling sugar syrup for 8-10 minutes.

For the preparation of malai 1.30 litre cow milk was heated in pan until $50 \%$ volume was reduced. Rassogolla were cooked in hot malai for 3-5 minutes. Then the Indrani vough was prepared and it was allowed to stay for sometimes to become cool. After 5-6 hours Indrani vough was ready for consumption. This laboratory made Indrani vough was labeled as 'A'.

\section{Collection and preservation market samples}

The samples of Indrani vough were collected from three different shops of Dinajpur district of Bangladesh and were labeled as: $B=$ Indrani vough collected from Shananda sweat meat shop, $\mathrm{C}=$ Collected from Pabna sweat meat shop, $\mathrm{D}=$ Collected from Jalozogh sweat meat shop. At first $1 \mathrm{~kg}$ of the Indrani vough sample from each shop was separately collected in each individual polythene bag with the help of spoon and the mouth of bag was tied with thread and was put the ice containing thermoflax by proper labeling. After collection, fifty percent samples were used for organoleptic evaluation and twenty five percent for determination of chemical composition and microbiological qualities.

\section{Organoleptic and chemical examination of samples}

Indrani vough made in the Laboratory and collected from different shops of Dinjpur district were judged by the panel of experienced judges for organoleptic properties such as flavour, body and texture, colour and appearance and taste using a score card. The score card was arranged as: flavour $=45$, body and texture $=30$, colour and appearance $=15$ and taste $=10$. Chemical tests were moisture, dry matter, protein, fat, carbohydrate and ash content determination by adopting AOAC (2003) methods. Acidity was determined by the titrating with $\mathrm{N} / 10$ sodium hydroxide solution using the procedure of Aggarwals and Sharma (1961).

\section{Microbiological examination}

Total viable count and coliform count of Indrani vough samples were done using standard plate count (S.P.C.) method according to American Public Health Association (APHA, 1998) for the assessment of microbiological status.

\section{Statistical analysis}

Data collected for different parameters were subjected to statistical analysis. In this experiment all the experimental materials were completely homogenous and for this reason the data were analysed by Completely Randomized Design (CRD) using MSTAT Statistical Programme (Gomez and Gomez 1984). Analysis of variance tests (ANOVA) were done to find out the statistically significant differences among the samples. 


\section{Coparison of Indrani Vough}

\section{Results and Discussion}

Still now no research work has yet been done in our country on the quality, manufacturing process and/or preservation technique of Indrani vough, The results are discussed below in reference with Rasomalai and Rasogolla.

\section{Flavour score}

Flavour score of all four sources of Indrani vough are presented on Table 1. Significant difference $(p<0.01)$ was found in respect of flavour score of different Indrani vough samples. Flavour score of B sample was the highest. The lowest score was obtained for sample D. These results are typical for sweetmeat similar to Rasagolla. According to Parvin (1996) the flavor score of rasogolla made from fresh cow milk was 40.57. Joshi et al. (1991) stated that chhana from cow milk and buffalo milk had acceptable flavour where as that from goat milk had acidic flavour.

\section{Body and texture score}

Statistical analysis showed that there was no significant difference between the Body and texture score of different types of Indrani vough sample (Table 1.). Higher body and texture score indicates the soft and spongy body where as the lower score indicates coarse body of prepared Rassogolla. Parvin (1996) stated that body and texture score fresh cow milk rasogolla was 25.97. Joshi et. al. (1991) reported that chhana prepared from cow milk and goat milk provides soft body and smooth texture. The result of this study was found to be similar.

\section{Colour and appearance score}

Table 1 . indicates that the colour and appearance score of different types of Indrani vough sample did not vary significantly. The minor variation in colour and appearance score of the Indrani vough samples were probably due to the variation in the composition of the milk used. Mini et al. (1995) described that Rasogolla made from cow milk secure higher score than Rasogolla prepared from skim milk filled with coconut oil for flavour, colour and appearance. The highest color and appearance score was 11.73 for cow milk rasogolla obtained by Parvin (1996).
Table 1. Comparison of average score of various organoleptic parameters of Indrani vough

\begin{tabular}{lcccc}
\hline \multirow{2}{*}{$\begin{array}{l}\text { Organoleptic } \\
\text { parameters }\end{array}$} & \multicolumn{4}{c}{ Type (Mean \pm SD) } \\
\cline { 2 - 5 } Flavor & $\mathrm{A}$ & $\mathrm{B}$ & $\mathrm{C}$ & $\mathrm{D}$ \\
\hline \multirow{2}{*}{ Body \& Texture } & $27.44^{\mathrm{b}}$ & $42.50^{\mathrm{a}}$ & $40.89^{\mathrm{b}}$ & $37.55^{\mathrm{c}}$ \\
& \pm 0.29 & \pm 0.10 & \pm 0.11 & \pm 0.99 \\
\hline \multirow{2}{*}{ Color \& Appearance } & 12.66 & 13.50 & 13.22 & 12.66 \\
& \pm 0.19 & \pm 0.10 & \pm 0.40 & \pm 0.19 \\
\hline \multirow{2}{*}{ Taste } & 8.83 & 9.22 & 8.44 & 8.72 \\
& \pm 0.44 & \pm 0.40 & \pm 0.29 & \pm 0.43 \\
\hline \multirow{2}{*}{ Overall score } & 88.43 & 93.72 & 90.77 & 86.43 \\
& \pm 0.88 & \pm 1.94 & \pm 2.99 & \pm 2.62 \\
\hline
\end{tabular}

Mean with different superscripts in a row very significantly $(p<0.01) ; A$, laboratory made Indrani vough; B, Indrani vough collected from Shananda sweet meat shop; C, Indrani vough collected from Pabna sweet meat shop; D, Indrani vough collected from Jalozogh sweet meat shop

\section{Taste score}

Insignificant difference among the taste scores of different types of Indrani vough samples was observed, but all the samples had acceptable pleasant taste. Parvin (1996) stated that taste score of fresh cow milk Rosogolla was 8.33.

\section{Overall score}

Aaverage scores for all the Organoleptic parameters of sample B was the highest but statistically all the values differ insignificantly. Total organoleptic score of fresh cow milk Rasogolla was 86.60 (Parvin, 1996.). Aurongozeb (2000) stated that the overall score (consisting flavour, body, and texture, color and appearance and taste) of samples containing 10, 5, 3 and $0 \%$ soy-flour were $85.20,86.05,88.00$ and 90.75 respectively. The highest score was found for samples having no soy-flour.

\section{Chemical parameters}

The different samples of Indrani vough were analyzed for their Moisture, Dry matter, Protein, Fat, Carbohydrate, Ash and Acidity contents. The results are presented in Table 2 .

\section{Dry matter content}

The dry matter content of Indrani vough samples A, B, C and D are presented in Table 2. Market Indrani vough samples contain slightly higher dry matter content than that of laboratory one. 
Table 2. Comparison of average chemical compositions of different types of Indrani vough

\begin{tabular}{lcccc}
\hline Chemical & \multicolumn{5}{c}{ Type (Mean \pm SD) } \\
\cline { 2 - 5 } Parameters & $\mathrm{A}$ & $\mathrm{B}$ & $\mathrm{C}$ & $\mathrm{D}$ \\
\hline Dry matter & 359.92 & 360.85 & 360.2 & 359.34 \\
(g/kg) & \pm 0.61 & \pm 0.21 & \pm 0.32 & \pm 0.23 \\
\hline Protein & $87.4^{\mathrm{ab}}$ & $89.73^{\mathrm{a}}$ & $84.67^{\mathrm{b}}$ & $71.6^{\mathrm{c}}$ \\
(g/kg) & \pm 0.17 & \pm 0.24 & \pm 0.09 & \pm 0.10 \\
\hline Fat (g/kg) & $81.66^{\mathrm{b}}$ & $84.66^{\mathrm{a}}$ & $80.66^{\mathrm{ab}}$ & $67.33^{\mathrm{c}}$ \\
& \pm 0.23 & $\pm 0.15^{\circ}$ & \pm 0.12 & \pm 0.12 \\
\hline Carbohydrate & $173.25^{\mathrm{bc}}$ & $174.26^{\mathrm{c}}$ & $189.87^{\mathrm{b}}$ & $201.59^{\mathrm{a}}$ \\
(g/kg) & \pm 0.20 & \pm 0.19 & \pm 0.22 & \pm 0.22 \\
\hline Ash (g/kg) & $11.61^{\mathrm{b}}$ & $10.11^{\mathrm{c}}$ & $12.98^{\mathrm{ab}}$ & $13.98^{\mathrm{a}}$ \\
& \pm 0.02 & \pm 0.01 & \pm 0.02 & \pm 0.01 \\
\hline Acidity (\%) & $0.30^{\mathrm{c}}$ & $0.42^{\mathrm{a}}$ & $0.39^{\mathrm{ab}}$ & $0.41^{\mathrm{b}}$ \\
& \pm 0.01 & \pm 0.001 & \pm 0.01 & \pm 0.01 \\
\hline
\end{tabular}

Mean with different superscripts in a row very significantly $(p<0.01) ; A$, laboratory made Indrani vough; $B$, Indrani vough collected from Shananda sweet meat shop; C, Indrani vough collected from Pabna sweet meat shop; D, Indrani vough collected from Jalozogh sweet meat shop

\section{Protein content}

Protein contents of different sources of Indrani vough are presented in Table 2 . Statistical analysis showed that protein content of Indrani vough samples vary significantly $(p<0.01)$. Sample B contained the highest protein. Protein content of Indrani vough samples vary depending upon the quality of chhana used. This result indicates that high quality chhana was used for the manufacture of Indrani vough sample collected from sananda sweet meat shoap. Islam et al. (2003) illustrated that protein content of milk vita Rassomalai and that of product collected from the three famous sweetmeat shops was 8.29 and $5.55-7.03 \%$ respectively.

\section{Fat content}

The mean of fat contents of A, B, C and D sources Indrani vough samples are demonstrated in Table 2. Differences were highly significant $(p<0.01)$ among those mean value. It was observed that Indrani vough sample of Sananda sweet meat shop had significantly high amount of fat than the other samples contained. Highest fat content of Shananda made Indrani vough indicated that it was made from high quality chhana rich in milk fat, probably collected from milk of indigenous cows. Yasmin et al. (2005) showed that fat content of laboratory made rossomalai was better $(80.0 \mathrm{~g} / \mathrm{kg}$ ) as compared to the products $(60.2$ $62.2 \mathrm{~g} / \mathrm{kg}$ ) collected from different districts of
Bangladesh. In this experiment laboratory made Indrani vough contained slightly lower fat content compared to good quality Indrani vough of Sananda sweet meat shop. This may be due to variation in composition of whole milk used for preparation of different types of indrani vough samples, as some of the milk may have been collected from crossbred cows.

\section{Carbohydrate content}

There was significant difference $(p<0.01)$ within the carbohydrate contents of different types of Indrani vough samples. Market sample contained more carbohydrate, which may be due to addition of higher amount of flour and sugar. This indicates that quality of market samples collected from different shops of Dinajpur district were inferior to Laboratory made Indrani vough sample. Because carbohydrate content of Indrani vough sample depends upon the addition of sugar and starchy materials.

\section{Ash content}

Ash content values with Significant differences $(p<0.01)$ among Indrani vough samples are presented on Table 2. In an experiment, Katra and Bhargava (1990) reported that higher ash and total carbohydrate decreased the sponginess of the product. So, it can be said that sample B was the best among the samples in respect of ash content.

\section{Acidity percentage}

Statistically significant differences in the acidity percentage of different types of Indrani vough samples were shown on Table 2. Yasmin et al. (2005) explained that acidity \% in Rossomalai of Laboratory made and of different districts (Range values) was 0.38 and $0.32-0.53 \%$.

\section{Microbiological status}

The microbiological status of the Indrani vough samples were determined by total viable content and coliform count using Standard Plate Count (S.P.C) method. The numbers of viable bacteria and coliform counts per gram of A, B, C and D Indrani vough samples are demonstrated in Table 3. Laboratory made Indrani vough had lower level of total viable count as compared to different Indrani vough samples. Lower bacterial content indicates that strict hygienic condition was maintained during milking, collection of samples and also during the manufacturing of Indrani vough sample. Village farmers or sweetmeat makers did not strictly maintain the sanitary 
practices during milking or production of market Indrani vough especially $D$ sample. So that greater number of bacteria easily got entrance into samples. Very poor quality of milk might be used in the manufacturing of $D$ Indrani vough sample.

Table 3. Comparison of various Microbiological parameters of Indrani vough

\begin{tabular}{lcccc}
\hline Microbiological & \multicolumn{5}{c}{ Type (Mean \pm SD) } \\
\cline { 2 - 5 } parameters & $\mathrm{A}$ & $\mathrm{B}$ & $\mathrm{C}$ & $\mathrm{D}$ \\
\hline Total viable & $3.62^{\mathrm{c}}$ & $3.82^{\mathrm{bc}}$ & $3.88^{\mathrm{b}}$ & $3.97^{\mathrm{a}}$ \\
count (log & \pm 0.02 & \pm 0.02 & \pm 0.01 & \pm 0.02 \\
count) CFU/g & & & & \\
\hline Coliform & 0.00 & $1.06^{\mathrm{a}}$ & $1.62^{\mathrm{a}}$ & $\begin{array}{c}1.59^{\mathrm{b}} \\
\text { count/g (log }\end{array}$ \\
$\begin{array}{l}\text { count) } \\
\text { co.00 }\end{array}$ & \pm 0.06 & \pm 0.06 & \pm 0.06 \\
\hline
\end{tabular}

Mean with different superscripts in a row very significantly $(p<0.01) ; A$, laboratory made Indrani vough; $B$, Indrani vough collected from Shananda sweet meat shop; C, Indrani vough collected from Pabna sweet meat shop; D, Indrani vough collected from Jalozogh sweet meat shop

\section{Conclusion}

The results of physical and chemical parameters showed that Indrani vough prepared in Shananda sweet meat shop was better than other samples. On the other hand, considering the microbiological parameters, Indrani vough manufactured in laboratory was superior to the market samples as strict sanitary practices were followed in the laboratory. So the technology adopted by Shananda sweet meat shop for manufacturing Indrani vough should be followed along with good hygienic practices to make a better quality product.

\section{Reference}

Aggarwala AC, Sharma A (1961). A Laboratory Manual of Milk Inspection. $4^{\text {th }}$ edn, Asia Peulishing House, Bomby, Calcutta, New Delhi, India.

American Public Health Association (APHA) (1998). Standard Methods for the Examination of Dairy Products. 20 edn.
Washington DC.

Association of Official Agricultural Chemists (AOAC) (2003). Official Methods of Analysis (10th Ed.). Washington, DC, USA.

Aurongozeb ATN (2000). Studies on processing of soy-flour fortified rasogolla. MS Thesis, Department of Food Technology and Rural Industries, Bangladesh Agricultural University, Mymensingh.

Gomez KA, Gomez AA (1984). Statistical procedure for Agricultural Research. Int. Rice Res. Inst. John Wiley and Sons. New York, Ckickerster, Brisbane, Toronto, Singapore, P. 139-240.

Islam MZ, Rahman SMR, Alam MM, Mannan AKMA (2003). Manufacture of Rassomalai and It's Quality Attributes: An Indigenous Milk Sweetmeat of Bangladesh. Pakistan J ournal of Nutrition, 2: 300-304.

Joshi SV, Majgaonkar SV, Toro VA (1991). Effect of different coagulants on yield and sensory quality of chhana prepared from milk of cow, buffalo and goat. Indian Journal of Dairy Science, 44: 380-383.

Katra RV, Bhargava VN (1990). Production of rasogolla from cow milk containing different levels of soy milk. Asian Journal of Dairy Research, 9: 175-180.

Mathur BN, Zanjad PN, Rao KVSS (1991). Paneer and Tofu: An v-xy appraisal of product and process synergies. Indian Dairyman, 47: 407-413.

Mini J, Mukundan M, Pavitharan K (1995). Utilization of skin milk filled with coconut milk for preparation of rasogolla. Journal of Veterinary and Animal Science, 26: 79-81.

Parvin S (1996). A comparative study on the production of rassogolla from fresh $X "$ cow milk and whole milk powder. MS Thesis, Department of Dairy Science, Bangladesh Agricultural University.

Yasmin S, Wadud A, I slam MN, Hasan T (2005). Study on the quality of the Rassomalai manufactured in laboratory and sweetmeat shops of different districts of Bangladesh. Journal of Bangladesh Agricultural University, 3: 71-76. 